\title{
Age, gender, peers, life skills and quality of life influence risk of cell phone addiction among college teachers in Karnataka, India : a state level epidemiological analysis
}

BS Pradeep ${ }^{1 *}$, Anusha B Shenoy ${ }^{2}$, S Shahane ${ }^{2}$, RN Srividya ${ }^{2}$, Mutharaju Arelingaiah ${ }^{3}$, Rochana D'Souza ${ }^{2}$, Lavanya Garady ${ }^{4}$, MK Jyoti ${ }^{5}$, Suma Rache², Anand Dixit ${ }^{2}$, Gananath Shetty Yekkar ${ }^{6}$, Prathap Lingaiah ${ }^{6}$, Shalini Rajneesh ${ }^{6}$ and G Gururaj ${ }^{7}$

\begin{abstract}
Background: Cell phones are an integral part of modern day life and have become companions for individuals irrespective of age, gender and socio-economic status. In this study, we assessed the factors affecting risk of cell phone addiction among teachers attending Life Skills Training and Counselling Services (LSTCS) program in Karnataka.

Methods: This cross sectional secondary data analysis utilised data from baseline assessment of trainees attending a Life Skills Training and Counselling Services program (LSTCP). Various factors hypothesised to be affecting risk of cell phone addiction (outcome) was analysed using univariate and multivariable logistic regression analysis. All the analysis was done using STATA 12.0 software.

Results: Multivariable logistic regression analysis was conducted with risk of cell phone addiction as outcome. A conceptual framework of hypothesized exposure variables was developed based on expert consultation and literature review. Overall, data of 1981 participants was utilized. Gender ( $A O R=1.91 ; 95 \% \mathrm{Cl}=1.27-2.77$ ), number of peers $(A O R=1.01 ; 95 \mathrm{Cl}=1-1.008)$ and social quality of life $(A O R=1.01 ; 95 \% \mathrm{Cl}=1.00-1.03)$ were associated with increased risk of cell phone addiction. Age ( $A O R=0.98 ; 95 \% \mathrm{Cl}=0.96-1.00)$, empathy ( $\mathrm{AOR}=0.96 ; 95 \% ; \mathrm{Cl}=0.93-0.99)$, communication skills(AOR $=0.92,95 \% ; C l=0.88-0.96)$ and physical quality of life ( $A O R=0.96 ; 95 \% \mathrm{Cl}=0.95-0.98$ ) were associated with reduced risk of cell phone addiction.
\end{abstract}

Conclusions: This study on precursors of risk of cell phone addiction, conducted mostly among apparently healthy individuals, provide important insights into interventions to reduce risk of cell phone addiction. The complexity of associations between peers, gender, quality of life and risk of cell phone addiction needs further exploration.

Keywords: Cell phone addiction, Technology addiction, Addictive behavior, Life skills, Quality of life

*Correspondence: doctorpradeepbs@gmail.com

1 Department of Epidemiology, Centre for Public Health, NIMHANS,

Bengaluru, India

Full list of author information is available at the end of the article

\begin{abstract}
Background
Cell phones are an integral part of modern day life. There are about 5.2 billion unique cell phone users in the world [1]. As on 2019, there were about 1161.17 million cell phone users in India [2]. Cell phones are known to affect individuals overall health [3]. They are associated with sleep deprivation [4], inappropriate food habits [5],
\end{abstract}

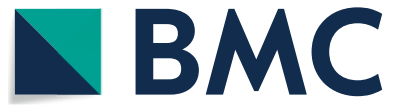

(c) The Author(s) 2022. Open Access This article is licensed under a Creative Commons Attribution 4.0 International License, which permits use, sharing, adaptation, distribution and reproduction in any medium or format, as long as you give appropriate credit to the original author(s) and the source, provide a link to the Creative Commons licence, and indicate if changes were made. The images or other third party material in this article are included in the article's Creative Commons licence, unless indicated otherwise in a credit line to the material. If material is not included in the article's Creative Commons licence and your intended use is not permitted by statutory regulation or exceeds the permitted use, you will need to obtain permission directly from the copyright holder. To view a copy of this licence, visit http://creativecommons.org/licenses/by/4.0/. The Creative Commons Public Domain Dedication waiver (http://creativeco mmons.org/publicdomain/zero/1.0/) applies to the data made available in this article, unless otherwise stated in a credit line to the data. 
physical inactivity, over weight and obesity [6]. Further, reduced social participation, interaction with family, friends and society [7], road traffic accidents and injuries $[8,9]$ are associated with overuse cell phone and its addiction. In India, the magnitude of cell phone addiction among adolescents range from 39 to 44\% [10]. Psychologically, cell phone use is attributed to loneliness, fatigue and stresses [11] and is a known precursor of consequent mental health problems [12].

Cell phones have become companions for individuals irrespective of age, gender and socio-economic status. This may lead to addiction amongst individuals. Various facets of cell phone addiction like "a state of sociopsychological illness", "nomophobia" (No-Mobile-phobia) [13], "textiety", "ringxiety", "textaphrenia", "phantom ringing/vibration syndrome", "commufaking" are described. Approximately 2/3rd of the world's population shows signs of nomophobia [14]. Excessive use of cellphone is also known to change brain chemistry [14]. Cell phone addiction is likely to affect an individual's familial and societal relationships as they grow old and has potential to become a major public health problem [15]. College teachers are important and crucial change makers in the society as they have the responsibility in shaping life of youth and students. Education is no exception in contributing to the rapid growth of technology. Cellphones are known to impact education, health, social life and business [16]. These can both be positive and negative. Usage of cell phone among teachers includes potential obstacles such as student cheating, addiction to internet information, cyberbullying and negative impact on student conduct etc. Over use of cell phone results in ignoring day to day activities and disregard their responsibilities and commitments resulting in behavior addiction [17]. This impacts their quality of life [18], attention span [19], poor professional performance [20]. Cell phones kill creativity and conversations [21]. Improper use of cell phones during office can affect students negatively resulting in their poor academic performance, inability to efficiently complete assigned curriculum and increased pressure leading to decreased quality of life [22].

Understanding specific factors that contribute to cell phone addiction is imperative in order to plan strategies to minimize or eliminate those risks whenever possible and increasing quality of life. Further, this helps clinicians, public health professionals, policy makers and experts to work effectively towards the cause of cell phone addiction. Most studies have looked at cell phone addiction and its risk factors among adolescents and young adults. Current study focuses on identifying the various factors contributing towards developing risk of cell phone addiction which aids in the personal and professional growth. This study aims to address the issue of risk of cell phone addiction among college teachers attending Life Skills training and Counselling Services program (LSTCP) in Karnataka, India.

\section{Methods}

This cross sectional secondary data analysis of various factors hypothesised to be affecting risk of cell phone addiction was conducted between January 2021 and March 2021. Secondary data from baseline assessment of trainees attending Life Skills Training and Counselling Services program (LSTCP) at National Institute of Mental Health and Neuro Sciences (NIMHANS), Bengaluru was utilised. Primarily the study was conducted to assess the effectiveness of Life skills training program among college teachers in Karnataka, India. The participants of LSTCP program are deputed mostly from within the government setup, namely directorates of collegiate education, technical education, pre-university board and 48 universities across 30 districts of Karnataka. Deputation of participants by their respective authorities is done on request by interested participants on a first-come-firstserved basis. Data collection was done by trained project staff, where clear instructions provided before administration and participants' questions were clarified during filling of responses. The primary data was collected using a pre-tested semi-structured self-administered pen and paper questionnaire, originally developed to assess effect of training on life skills of participants of LSTCP. This study instrument comprised of 25 sections (supplementary file 1). For this data analysis 10 out of these 25 sections namely socio-demographic details, sections on behaviour related to chewing and smoking tobacco, consuming alcohol, sniffing and injecting drugs, details of physical activity, information related to their occupation and peer characteristics, level of life skills and quality of life were utilised. Information on risk of cell phone addiction was utilised as outcome.

Risk of cell phone addiction was assessed utilizing a 6-item questionnaire developed by the Centre for WellBeing NIMHANS, Bengaluru [7]. A conceptual frame work was developed depicting hypothesised exposure variables affecting risk of cell phone addiction (Fig. 1). A conceptual framework of factors affecting risk of cellphone addiction was developed based on stakeholder/ expert consultation. These involved public health specialists, psychologists, psychiatrists, community development experts, teachers and youth. Broadly, these factors included socio-demographic factors, behavioural factors (chewing and smoking of tobacco, alcohol use, other substance use and personality traits), environmental factors (family environment, personal and family health, work and job satisfaction), individuals life skills score and quality of well-being scores. 


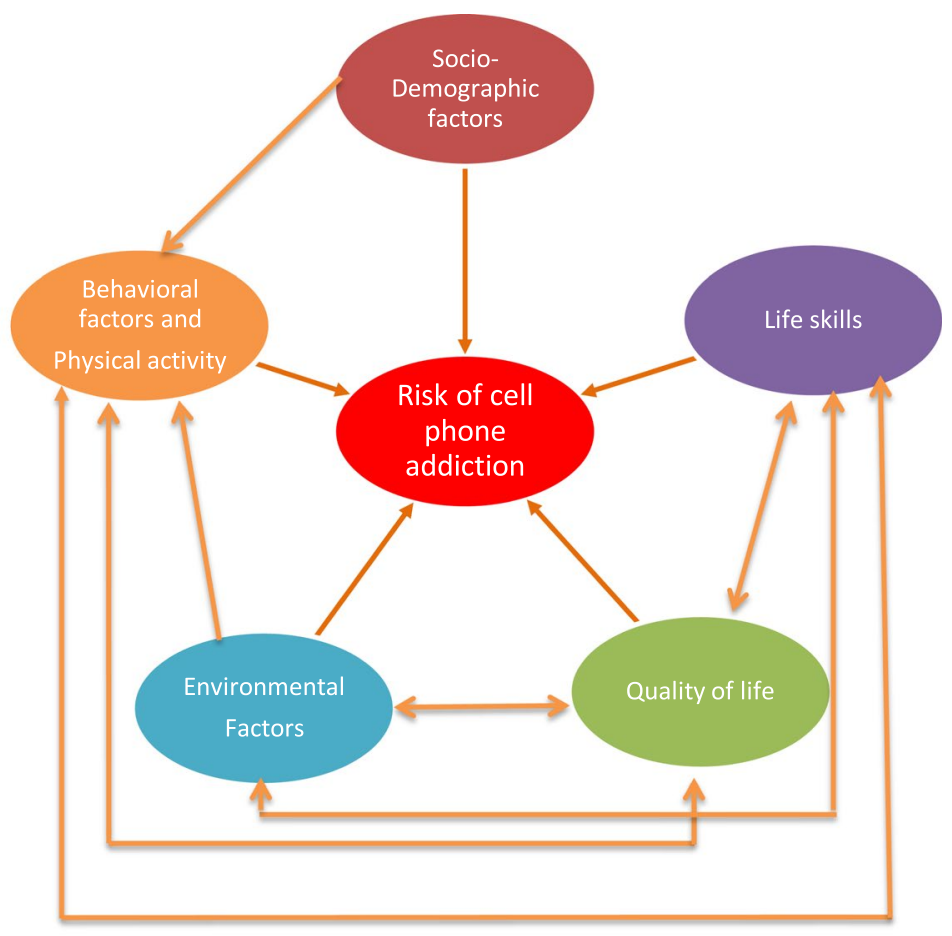

1. Unidirectional

2. Bidirectional

Fig. 1 Conceptual framework of hypothesised factors associated with risk of cell phone addiction

\section{Statistical analysis}

Univariate logistic regression analysis was performed with risk of cell phone addiction as outcome variable. Variables in the conceptual framework were considered as exposure variables. In univariate analysis, all hypothesised exposure variables associated with the outcome at $10 \%$ significance $(\mathrm{p}<0.10)$ was eligible to be considered for the final multivariable logistic regression model. A forward stepping process was used to build the final model. Variables that were significant at 5\% level $(\mathrm{p}<0.05)$ and those which changed the odds ratio of at least one exposure variable by $10 \%$ were eligible to be retained in the final model. The significance of addition of each exposure variable into the model was tested using likelihood ratio test with appropriate degrees of freedom. This was done by comparing the nested model with the previous model. Goodness of fit for the final model was tested using estat gof command followed by fitting area under the curve using lroc command. All the analysis was done using STATA 12.0 software for WINDOWS [23]. All the necessary ethical guidelines and principles were followed in the conduct of this study. The ethical approval for the study was obtained from institutional ethics committee of NIMHANS vide letter No. NIMHANS $/ 2^{\text {ND }}$ IEC (BS \& NS DIV.)/2016 dated 07/12/2016. The primary data collection among participants of LSTCS program was done with written informed consent of the participants.

\section{Results}

This study had 1981 participants. Among them, the majority were men (72.38\%), mostly urban (59.99\%), practiced hindu religion $(92.67 \%)$, post graduates $(89.16 \%)$ and currently married $(77.17 \%)$. Mean age of participants at risk of cell phone addiction $(37.82 \pm 9.43$ years) was significantly lower compared to those who were not at risk $(39.67 \pm 8.63)$ of cell phone addiction. Gender $(\mathrm{p}=0.001)$, education $(\mathrm{p}=0.039)$ and marital status $(p=0.002)$ of participants was associated with risk of cell phone addiction (Table 1).

Majority of the participants reported to be involved in daily physical activity (85.07\%). Among them almost $3 / 4$ th $(87.62 \%)$ reported to be involved in moderate physical activity. About $20.72 \%(n=357)$ of the participants reported to feel excessively anxious. More than half of the participants reported to engage in self-talk (57.32\%) and about $4.29 \%$ reported of having suicidal thoughts. Approximately, 1/3rd of the participants reported to have consumed alcohol (29.04\%) and $13.28 \%$ reported to have ever smoked. Daily physical activity, feeling depressed, feeling excessively anxious, participants who engage in 
Table 1 Socio-demographic characteristics and risk of cell phone addiction among LSTCP participants

\begin{tabular}{|c|c|c|c|c|c|c|c|}
\hline \multirow{3}{*}{$\begin{array}{l}\text { Socio demographic } \\
\text { characteristics }\end{array}$} & \multicolumn{4}{|c|}{ Risk of cell phone addiction } & \multirow{2}{*}{\multicolumn{2}{|c|}{ Total }} & \multirow[t]{3}{*}{${ }^{*} p$ value } \\
\hline & \multicolumn{2}{|c|}{ Present } & \multicolumn{2}{|c|}{ Absent } & & & \\
\hline & $\mathbf{N}$ & $\%$ & $\mathrm{~N}$ & $\%$ & $\mathrm{~N}$ & $\%$ & \\
\hline $\operatorname{Age}^{\$}(n=1927)$ & 37.82 & 9.43 & 39.67 & 8.63 & 39.44 & 8.76 & $0.003^{\natural}$ \\
\hline \multicolumn{8}{|l|}{ Gender $(n=1937)$} \\
\hline Female & 42 & 7.85 & 493 & 92.15 & 535 & 27.62 & \multirow[t]{2}{*}{$0.001^{\pi}$} \\
\hline Male & 188 & 13.41 & 1214 & 86.59 & 1402 & 72.38 & \\
\hline \multicolumn{8}{|l|}{ Locale $(n=1937)$} \\
\hline Rural & 104 & 13.42 & 671 & 86.58 & 775 & 40.01 & \multirow[t]{2}{*}{0.086} \\
\hline Urban & 126 & 10.84 & 1036 & 89.16 & 1162 & 59.99 & \\
\hline \multicolumn{8}{|l|}{ Religion $(n=1937)$} \\
\hline Hindu & 216 & 12.03 & 1579 & 87.13 & 1795 & 92.67 & \multirow[t]{2}{*}{0.44} \\
\hline Others & 14 & 9.86 & 125 & 90.14 & 142 & 7.33 & \\
\hline \multicolumn{8}{|l|}{ Education $(n=1937)$} \\
\hline Till PUC & 4 & 16.67 & 20 & 83.33 & 24 & 1.24 & \multirow[t]{3}{*}{$0.039^{\natural}$} \\
\hline Degree/Diploma & 32 & 17.2 & 154 & 82.8 & 186 & 9.6 & \\
\hline PG and above & 194 & 11.23 & 1533 & 88.77 & 1727 & 89.16 & \\
\hline \multicolumn{8}{|c|}{ Marital status $(n=1934)$} \\
\hline Currently married & 160 & 10.65 & 1343 & 89.35 & 1503 & 77.71 & \multirow[t]{3}{*}{$0.002^{\sharp}$} \\
\hline Never married & 66 & 17.23 & 317 & 82.77 & 383 & 19.8 & \\
\hline Others & 4 & 8.33 & 44 & 91.67 & 48 & 2.48 & \\
\hline
\end{tabular}

* $p$ value for chi-square test for independence for categorical variables/fisher's exact test for categorical variables and t-test for difference between two means for continuous variables ${ }^{\$}$ Numbers indicate Mean and Standard deviation in place of number and percentage, "significant at $p<0.05$

self-talk, those who ever smoked, ever injected drugs to get high and personality traits such as extraversion, agreeableness, conscientiousness and neuroticism were all significantly associated with risk of cell phone addiction among the study participants (Table 2).

Majority of the participants spend time with their family (96.07\%), participate in regular picnics and social gatherings $(95.23 \%)$, take collective decisions in family (76.54\%) and have good family support (67.41\%). Participation in social gatherings within the family, decision making within the family, job satisfaction, number of peers and having health problems were associated with risk of cell phone addiction among participants attending LSTCP (Table 3).

Overall, increasing life skills scores and quality of life scores across domains were significantly associated with reduced risk of cell phone addiction except creative thinking scores (Table 4).

In multivariable logistic regression analysis, participant's age and gender; number of peers the participant reported to be having; empathy and communication skills; physical and social quality of life were significantly associated with risk of cell phone addiction among participants of LSTCP (Table 5). For every unit increase in age, the odds of cell phone addiction decreased by $2 \%$ $(\mathrm{AOR}=0.98 ; 95 \% \mathrm{CI}=0.96-1.00)$. Male participants had almost 2 times higher odds of cell phone addiction compared to female participants (AOR $=1.91 ; 95 \% \mathrm{CI}=1.27$ 2.77). Increase in number of peers was associated with increased odds of cell phone addiction $(\mathrm{AOR}=1.01 ; 95$ $\mathrm{CI}=1-1.008)$. Among the different life skills domains every unit increase in empathy $(\mathrm{AOR}=0.96$; $95 \%$ $\mathrm{CI}=0.93-0.99)$ and communication skills $(\mathrm{AOR}=0.92$; 95\% $\mathrm{CI}=0.88-0.96)$ was associated with $4 \%$ and $8 \%$ reduction in odds of cell phone addiction respectively. Every unit increase in physical quality of life $(\mathrm{AOR}=0.96$; $95 \% \mathrm{CI}=0.95-0.98)$ was associated with $4 \%$ reduction in odds of cell phone addiction while every unit increase in social quality of life score $(\mathrm{AOR}=1.01 ; 95 \% \mathrm{CI}=1.00$ 1.03 ) was associated with $1 \%$ increased odds of cell phone addiction.

\section{Discussion}

Our study throws light on the factors associated with risk of cell phone addiction among LSTCP participants. Gender, number of peers and social quality of life were associated with increased risk of cell phone addiction. Age; empathy; communication skills and physical quality of life were associated with reduced risk of cell phone addiction among participants of LSTCP (Table 5).

Younger individuals lack self-control and prudence for appropriate utilization of cellphones [24-27]. It is known 
Table 2 Physical activity, behavioral factors, substance use characteristics and risk of cellphone addiction among LSTCP participants

\begin{tabular}{|c|c|c|c|c|c|c|c|c|c|}
\hline \multirow[t]{3}{*}{ Physical activity, behavioral factors and substance use } & \multicolumn{5}{|c|}{ Risk of cell phone addiction } & & \multirow{2}{*}{\multicolumn{2}{|c|}{ Total }} & \multirow[t]{3}{*}{$p$ value* } \\
\hline & \multicolumn{3}{|c|}{ Present } & \multicolumn{3}{|c|}{ Absent } & & & \\
\hline & $\mathbf{n}$ & $\%$ & & $\mathrm{n}$ & $\%$ & & $\mathbf{N}$ & $\%$ & \\
\hline \multicolumn{10}{|l|}{ Physical activity $(n=1915)$} \\
\hline Daily routine involves physical activity & 181 & 11.11 & & 1448 & 88.89 & & 1629 & 85.07 & $0.01^{\natural}$ \\
\hline \multicolumn{10}{|l|}{ Type of physical activity $(n=1623)^{* *}$} \\
\hline Sedentary & 20 & 15.5 & & 109 & 84.5 & & 129 & 7.95 & 0.249 \\
\hline Moderate & 152 & 10.69 & & 1270 & 89.31 & & 1422 & 87.62 & \\
\hline Vigorous & 8 & 11.11 & & 64 & 88.89 & & 72 & 4.44 & \\
\hline \multicolumn{10}{|l|}{ Behavioral characteristics /Psychological wellbeing } \\
\hline Ever smoked tobacco $(n=1928)$ & 41 & 16.02 & & 215 & 83.98 & & 256 & 13.28 & $0.03^{\mathbb{q}}$ \\
\hline Currently smoking tobacco $(n=226)$ & 14 & 19.18 & & 59 & 80.82 & & 73 & 32.3 & 0.178 \\
\hline Ever used smokeless tobacco $(n=1915)$ & 14 & 15.05 & & 79 & 84.95 & & 93 & 4.86 & 0.346 \\
\hline Currently using smokeless tobacco $(n=86)$ & 3 & 10 & & 27 & 90 & & 30 & 34.88 & 0.529 \\
\hline Ever consumed alcohol $(n=1911)$ & 72 & 12.97 & & 483 & 87.03 & & 555 & 29.04 & 0.37 \\
\hline Ever used injecting drugs to get high $(n=1909)$ & 6 & 25 & & 18 & 75 & & 24 & 1.26 & $0.047^{\Uparrow}$ \\
\hline Ever used sniffing drugs to get high $(n=1920)$ & 3 & 21.43 & & 11 & 78.57 & & 14 & 0.73 & 0.226 \\
\hline Feel depressed $(n=1588)$ & 4 & 33.33 & & 8 & 66.67 & & 12 & 0.76 & $0.037^{\pi}$ \\
\hline Feel excessively anxious $(n=1723)$ & 66 & 18.49 & & 291 & 81.51 & & 357 & 20.72 & $<0.001^{\circledR}$ \\
\hline Suicidal ideation $(n=1912)$ & 15 & 18.29 & & 67 & 81.71 & & 82 & 4.29 & 0.072 \\
\hline Self-harm $(n=1828)$ & 4 & 26.67 & & 11 & 73.33 & & 15 & 0.82 & 0.088 \\
\hline Self-talk $(n=1912)$ & 144 & 13.14 & & 952 & 86.86 & & 1096 & 57.32 & $0.047^{\curvearrowleft}$ \\
\hline \multicolumn{10}{|l|}{ Personality traits } \\
\hline & Mean & SD & Mean & & SD & Mean & & SD & \\
\hline Extraversion score $(n=1902)$ & 3.29 & 0.8 & & 3.51 & 0.78 & & 3.49 & 0.78 & $<0.001^{\circledR}$ \\
\hline Agreeableness score $(n=1906)$ & 3.7 & 0.66 & & 3.86 & 0.65 & & 3.85 & 0.66 & $<0.001^{9}$ \\
\hline Conscientiousness score $(n=1909)$ & 3.87 & 0.74 & & 4.08 & 0.66 & & 4.06 & 0.68 & $<0.001^{\natural}$ \\
\hline Neuroticism score $(n=1912)$ & 2.44 & 0.79 & & 2.14 & 0.72 & & 2.17 & 0.73 & $<0.001^{\circledR}$ \\
\hline Openness score $(n=1919)$ & 3.13 & 0.45 & & 3.13 & 0.42 & & 3.13 & 0.42 & 0.84 \\
\hline
\end{tabular}

${ }^{*} p$ value of fisher's exact test, chi-square test for independence for categorical variables/t-test for difference between two means for continuous variables, ${ }^{\$}$ Numbers indicate Mean and Standard deviation(SD) in place of number and percentage, ${ }^{* *}$ Among those participants whose daily routine involved physical activity, "significant at $p<0.05$

that younger individuals are more tech savvy and comfortable using cell phones compared to older individuals. Similar to other studies, we report, decreased risk of cell phone addiction with age. In addition, reduced adaptability in advancement of cell phones may contribute to reduced usage and subsequent risk of cell phone addiction among older individuals. This might be the case with our study population of teachers. Association of gender with cell phone addiction is not consistent across studies [28]. In conformity with few studies, we found that risk of cell phone addiction is more among men compared to women [27, 29]. However, there are other studies which report either no difference in risk [30,31] or increased risk among women [32]. There is a need to explore this inconsistent association of gender with risk of cell phone addiction.
In our study, increasing number of peers increased the risk of cell phone addiction. Better social quality of life was also associated with increased risk of cell phone addiction. This might be a reflection of increased interaction with peers through social media and instant messaging platforms (IMPs). It is likely for the participants to consider their contacts in social media and IMPs as peers. In addition, participants are likely to be utilising cell phones for their social interactions with those peers with whom in-person interaction was not possible. However, this information was not verified during data collection. As per our knowledge there is only one study related to peers and cell phone addiction inferring that peer satisfaction lowers the risk of cell phone addiction [33]. There are no studies looking at number of peers and cell phone addiction risk. It is likely that number of peers 
Table 3 Environmental factors and risk of cellphone addiction among LSTCP participants

\begin{tabular}{|c|c|c|c|c|c|c|c|}
\hline \multirow[t]{3}{*}{ Family and social characteristics } & \multicolumn{4}{|c|}{ Risk of cell phone addiction } & \multirow{2}{*}{\multicolumn{2}{|c|}{ Total }} & \multirow[t]{3}{*}{$p$ value* } \\
\hline & \multicolumn{2}{|c|}{ Present } & \multicolumn{2}{|c|}{ Absent } & & & \\
\hline & $\mathbf{N}$ & $\%$ & $\mathbf{N}$ & $\%$ & $\mathbf{N}$ & $\%$ & \\
\hline Spend time with family $(n=1934)$ & 218 & 11.73 & 1640 & 88.27 & 1858 & 96.07 & 0.284 \\
\hline Participate in social gatherings with family $(n=1929)$ & 210 & 11.43 & 1627 & 88.57 & 1837 & 95.23 & $0.003^{\pi}$ \\
\hline \multicolumn{8}{|l|}{ Decision making in family $(n=1931)$} \\
\hline Collectively make decision & 163 & 11.03 & 1315 & 88.97 & 1478 & 76.54 & $0.049^{\pi}$ \\
\hline I make decision & 56 & 15.64 & 302 & 84.36 & 358 & 18.54 & \\
\hline Somebody else make decision & 10 & 10.53 & 85 & 89.47 & 95 & 4.92 & \\
\hline \multicolumn{8}{|l|}{ Justification of arguments within the family $(n=1312)$} \\
\hline Completely justified & 34 & 11.93 & 251 & 88.07 & 285 & 21.72 & 0.175 \\
\hline Usually justified & 60 & 10.95 & 488 & 89.05 & 548 & 41.77 & \\
\hline Sometimes justified & 67 & 15.58 & 363 & 84.42 & 430 & 32.77 & \\
\hline Not at all justified & 7 & 14.29 & 42 & 85.71 & 49 & 3.73 & \\
\hline \multicolumn{8}{|l|}{ Family support $(n=1918)$} \\
\hline Completely supportive & 149 & 11.52 & 1144 & 88.48 & 1293 & 67.41 & 0.359 \\
\hline Usually supportive & 55 & 11.96 & 405 & 88.04 & 460 & 23.98 & \\
\hline Sometimes supportive & 20 & 13.99 & 123 & 86.01 & 143 & 7.46 & \\
\hline Not at all supportive & 5 & 22.73 & 17 & 77.27 & 22 & 1.15 & \\
\hline Participant has health related problems & 96 & 13.99 & 590 & 86.01 & 686 & 35.53 & $0.036^{\pi}$ \\
\hline \multicolumn{8}{|l|}{ Had been diagnosed with a health problem } \\
\hline Hypertension $(n=679)$ & 29 & 13.24 & 190 & 86.76 & 219 & 32.25 & 0.803 \\
\hline Diabetes mellitus $(n=678)$ & 23 & 15.23 & 128 & 84.77 & 151 & 22.27 & 0.2 \\
\hline Thyroid disorders $(n=678)$ & 10 & 10 & 90 & 90 & 100 & 14.75 & 0.199 \\
\hline Rheumatic heart disease $(n=678)$ & 6 & 23.08 & 20 & 76.92 & 26 & 3.83 & 0.23 \\
\hline Congenital heart disease $(n=678)$ & 1 & 16.67 & 5 & 83.33 & 6 & 0.88 & 0.371 \\
\hline Other cardiac disorders $(n=678)$ & 2 & 12.5 & 14 & 87.5 & 16 & 2.36 & 0.468 \\
\hline Stroke $(n=678)$ & 0 & 0 & 7 & 100 & 7 & 1.03 & 0.647 \\
\hline Cancer $(n=678)$ & 1 & 20 & 4 & 80 & 5 & 0.74 & 0.591 \\
\hline Mental health problems $(n=678)$ & 13 & 16.46 & 66 & 83.54 & 79 & 11.65 & 0.369 \\
\hline \multicolumn{8}{|l|}{ Job satisfaction $(n=1910)$} \\
\hline Strongly satisfied & 133 & 10.48 & 1136 & 89.52 & 1269 & 66.44 & $0.002^{\pi}$ \\
\hline Satisfied & 72 & 13.16 & 475 & 86.84 & 547 & 28.64 & \\
\hline Neither satisfied nor dissatisfied & 17 & 22.67 & 58 & 77.33 & 75 & 3.93 & \\
\hline Dissatisfied & 3 & 42.86 & 4 & 57.14 & 7 & 0.37 & \\
\hline Strongly dissatisfied & 1 & 8.33 & 11 & 91.67 & 12 & 0.63 & \\
\hline Participants stay away from family for work $(n=1918)$ & 146 & 12.67 & 1006 & 87.33 & 1152 & 60.06 & 0.138 \\
\hline Number of peers ${ }^{n}$ & 50 & 85 & 25 & 85 & 25 & 85 & $0.019^{9}$ \\
\hline Member of any groups, organization or association $(n=1899)$ & 107 & 12.23 & 768 & 87.77 & 875 & 46.08 & 0.543 \\
\hline
\end{tabular}

${ }^{*} p$ value of fisher's exact test, chi-square test for independence for categorical variables, Mann-Whitney $\mathrm{U}$ test, ${ }^{\mathrm{n}}$ Median with interquartile range, "significant at $p<0.05$

and peer satisfaction might be correlated. However, this data was not collected in our study.

Among the ten life skills domains, every unit increase in scores of empathy and communication skills reduced the risk of cell phone addiction by $4 \%$ and $8 \%$ respectively. As explained by Funk and Buchman, exposure to media and cyberspace influences the behaviour of individual [34]. Use of any gadget for long duration is known to have negative impact on empathy and vice versa [34]. Further, higher smart phone addiction score is known to have negative impact on interpersonal communication [35]. Logically, when there are people around to communicate and empathise with each other, the urge to use a cell 
Table 4 Life skills, quality of life and risk of cell phone addiction among participants attending LSTCP

\begin{tabular}{|c|c|c|c|c|c|c|c|c|c|}
\hline \multirow[t]{3}{*}{ Life skills and quality of life } & \multicolumn{4}{|c|}{ Risk of cell phone addiction } & \multirow{2}{*}{\multicolumn{2}{|c|}{ Total }} & \multirow[t]{3}{*}{ Crude Odds ratio } & \multirow{3}{*}{$\begin{array}{l}\text { Confidence } \\
\text { interval at } \\
95 \%\end{array}$} & \multirow[t]{3}{*}{${ }^{*} p$ value } \\
\hline & \multicolumn{2}{|c|}{ Present } & \multicolumn{2}{|c|}{ Absent } & & & & & \\
\hline & Mean & SD & Mean & SD & Mean & SD & & & \\
\hline Decision making $(n=1937)$ & 35.23 & 3.94 & 36.84 & 3.86 & 36.64 & 3.9 & 0.902 & $0.87-0.93$ & $<0.001^{\circledR}$ \\
\hline Problem solving $(n=1937)$ & 51.34 & 6.07 & 53.99 & 5.91 & 53.68 & 6.07 & 0.933 & $0.91-0.95$ & $<0.001^{\natural}$ \\
\hline $\operatorname{Empathy}(\mathrm{n}=1937)$ & 45.35 & 5.55 & 48.36 & 5.49 & 48 & 5.58 & 0.911 & $0.89-0.93$ & $<0.001^{\natural}$ \\
\hline Self-awareness $(n=1937)$ & 40.05 & 4.96 & 41.36 & 4.59 & 41.2 & 4.65 & 0.945 & $0.92-0.97$ & $<0.001^{\natural}$ \\
\hline Communication skills $(n=1937)$ & 36.55 & 4.07 & 39.03 & 4.31 & 38.73 & 4.31 & 0.874 & $0.85-0.90$ & $<0.001^{\natural}$ \\
\hline Interpersonal relationship skills $(n=1937)$ & 70.36 & 7.68 & 73.47 & 6.89 & 73.1 & 7.1 & 0.943 & $0.93-0.96$ & $<0.001^{\natural}$ \\
\hline Coping with emotions $(n=1937)$ & 34.64 & 4.27 & 36.13 & 3.89 & 35.95 & 3.97 & 0.915 & $0.88-0.95$ & $<0.001^{\natural}$ \\
\hline Coping with stress $(n=1937)$ & 34.13 & 4.28 & 34.73 & 4.06 & 34.66 & 4.09 & 0.966 & 0.93-0.99 & $<0.001^{\natural}$ \\
\hline Creative Thinking $(n=1937)$ & 54.38 & 7.5 & 54.07 & 7.07 & 54.1 & 7.12 & 1.006 & $0.99-1.03$ & 0.533 \\
\hline Critical thinking $(n=1937)$ & 38.7 & 5.49 & 39.44 & 4.91 & 39.35 & 4.98 & 0.971 & $0.95-0.99$ & $0.034^{\pi}$ \\
\hline Overall life skill score $(n=1937)$ & 440.74 & 41.98 & 457.42 & 39.28 & 455.44 & 39.97 & 0.99 & $0.98-0.99$ & $<0.001^{\natural}$ \\
\hline Overall quality of life and health satisfaction $(n=1932)$ & 8.05 & 1.18 & 8.28 & 1.08 & 8.25 & 1.1 & 0.835 & $0.74-0.94$ & $0.003^{n}$ \\
\hline Physical quality of life $(n=1917)$ & 72.93 & 12.74 & 79.33 & 12.08 & 78.56 & 12.33 & 0.962 & $0.95-0.97$ & $<0.001^{\natural}$ \\
\hline Psychological quality of life $(n=1901)$ & 68.79 & 12.63 & 71.01 & 10.73 & 70.74 & 10.99 & 0.982 & $0.97-0.99$ & $0.005^{\natural}$ \\
\hline Social quality of life $(n=1810)$ & 75.89 & 16.51 & 78.84 & 15.61 & 78.48 & 15.74 & 0.989 & $0.98-0.99$ & $0.01^{\natural}$ \\
\hline Environmental quality of life $(n=1915)$ & 67.46 & 13.57 & 71.77 & 13.03 & 71.25 & 13.17 & 0.976 & $0.97-0.98$ & $<0.001^{\natural}$ \\
\hline
\end{tabular}

${ }^{*} p$ value for univariate logistic regression; " significant at $p<0.05$; SD is Standard deviation

Table 5 Multiple logistic regression analysis of factors affecting risk of cell phone addiction among participants attending LSTCP $(n=1726)$

\begin{tabular}{|c|c|c|c|c|c|c|}
\hline Characteristics & Crude odds ratio & $\begin{array}{l}\text { 95\% Confidence } \\
\text { interval }(\mathrm{CI})\end{array}$ & $p$ value $^{\mathrm{a}}$ & $\begin{array}{l}\text { Adjusted odds } \\
\text { ratio(AOR) }\end{array}$ & $95 \% \mathrm{Cl}$ & $p$ value ${ }^{*}$ \\
\hline Age & 0.98 & $0.96-0.99$ & $0.003^{b}$ & 0.98 & $0.96-1.00$ & $0.026^{b}$ \\
\hline $\begin{array}{l}\text { Gender } \\
\text { Female } \\
\text { Male }\end{array}$ & $\begin{array}{l}\text { Reference } \\
1.82\end{array}$ & $\begin{array}{l}\text { Reference } \\
1.28-2.58\end{array}$ & $\begin{array}{l}\text { Reference } \\
0.001^{b}\end{array}$ & $\begin{array}{l}\text { Reference } \\
1.91\end{array}$ & $\begin{array}{l}\text { Reference } \\
1.27-2.77\end{array}$ & $\begin{array}{l}\text { Reference } \\
0.002^{\mathrm{b}}\end{array}$ \\
\hline Number of peers & 1.005 & $1.001-1.008$ & $0.007^{b}$ & 1.005 & $1-1.008$ & $0.023^{b}$ \\
\hline Empathy score & 0.91 & $0.89-0.93$ & $<0.001^{b}$ & 0.96 & 0.93-0.99 & $0.012^{b}$ \\
\hline Communication skills score & 0.87 & $0.85-0.93$ & $<0.001^{\mathrm{b}}$ & 0.92 & $0.88-0.96$ & $<0.001^{b}$ \\
\hline Physical quality of life & 0.96 & $0.95-0.97$ & $<0.001^{b}$ & 0.96 & $0.95-0.98$ & $<0.001^{b}$ \\
\hline Social quality of life & 0.98 & $0.98-1$ & $0.01^{b}$ & 1.01 & $1.00-1.03$ & $0.014^{b}$ \\
\hline
\end{tabular}

${ }^{a}$ crude and adjusted $\mathrm{p}$ value of univariate and multiple logistic regression and ${ }^{\mathrm{b}}$ significant at $p<0.05$

Goodness of fit (Area Under the Curve) $=0.72$; Hosmer lemeshow chi $2=1661.36, p=0.819$

phone will likely reduce with subsequent reduction in risk of cell phone addiction.

It is known that quality of life impacts negatively on risk of cell phone addiction among the young [36]. We found that physical quality of life significantly reduced the risk and social quality of life increased the risk of cell phone addiction. Another study [37] among adolescents showed negative correlation of physical, psychosocial and overall quality of life with smart phone addiction. The difference in age group of study population might be the reason for the contradictory results between these studies.
In addition, difference in study instruments, sampling design and social contexts might affect these contradictory findings. The complexity associated with risk of cell phone addiction and different domains of quality of life emphasize the need to further examine these influences to inform interventions to improve quality of life.

The use of cell phones is becoming universal and an integral part in everyday life of individuals. This study comprehensively assessed 61 hypothesised factors associated with risk of cell phone addiction rather than factors associated with cell phone addiction. This provides 
an opportunity to intervene at a higher level in the pathway of development of cell phone addiction. Most studies on cell phone addiction have focused on adolescent and young population [10, 24, 36-38]. This study is conducted on largely adult population (mean age $=39.44 \pm 8.76$ ), mostly literate, married and post graduates. The results of this study are generalizable only to this population and contribute to the existing knowledge related to cell phone addiction beyond adolescent and young population.

The risk of cell phone addiction was assessed using standardised and validated tool developed by the centre for wellbeing NIMHANS, Bengaluru. This tool is utilized routinely in clinical practice to detect risk of cell phone addiction. There are many tools to assess technology addiction namely game addiction [39, 40], smartphone addiction [30], television addiction [41], internet addiction $[42,43]$ etc. This study used secondary data of individuals attending LSTCP. Primarily, the data for LSTCP was collected to assess factors affecting life skills. This is a 57-page questionnaire with 25 sections. Thus, the NIMHANS centre for wellbeing scale on risk of cell phone addiction being a small 6-item questionnaire was included as a factor affecting life skills. The scales used to assess quality of life and life skills are both standardised and validated for use [44, 45]. The Big5 inventory utilized to assess personality traits of participants is also a standardised and validated tool for use among adult population [46]. Furthermore, the large sample size, participants from various districts across Karnataka and utilizing secondary data adds to the strengths of the results of the study.

\section{Limitations}

The study is not without limitations. The participants of LSTCP program are deputed mostly from within the government setup, namely directorates of collegiate education, technical education, pre-university board and 48 universities across 30 districts of Karnataka. Although the selection of participants is on deputation, there is considerable geographic representation of participants from across the state. On an average there are approximately 66 participants deputed per district. We expect that these deputed officers are no different from those who are not deputed. Hence, we feel that the influence of selection bias related to outcome is either unlikely or negligible. However, to our knowledge, supporting evidence for the same is not available in current existing literature. Data collection using self-administered questionnaire offers limited control over the responses provided as well as the order in which respondent fills the questionnaire. However, the presence of one of our project team members to facilitate respondents, while filling the questionnaire as well as providing clear instruction and informed consent prior to questionnaire administration is likely to minimize this limitation. However, the data collection being self-administered, and training of project team is likely to ensure minimizing the effect of this bias and overall outcome. The presence of team member was also to clarify the doubts of the participants if they had any and there was no pressure/forcing on respondents for desirable answer in favor of the study. Highest level of control over the questionnaire was with the participants as it was a self-administered questionnaire reducing the interviewer and social desirability bias.

\section{Conclusion}

Despite limitations, this study has important implications for researchers and practitioners working on health promotion related to technology or cell phone or internet addiction among adults especially teachers. This study, being focused on precursors of risk of cell phone addiction, conducted mostly among apparently healthy individuals provides important insights into interventions upstream. Health promotion programs related to cell phone use among teachers could utilise these findings while designing interventions. However, the complexity of associations between quality of life and risk of cell phone addiction, number of peers and risk of cell phone addiction, various aspects of peer involvement like quality of peer association, satisfaction with peers need further exploration.

\section{Abbreviations}

LSTCS/P: Life Skills Training and Counselling Services /Program; AOR: Adjusted odds ratio; Cl: Confidence interval IMP: Instant messaging platform; IMP: Instant messaging platform.

\section{Supplementary Information}

The online version contains supplementary material available at https://doi. org/10.1186/s12889-022-12575-5.

\section{Additional file 1.}

\section{Acknowledgements}

Not applicable.

\section{Authors' contributions}

PBS - Conceptualization and design, project investigation, funding acquisition, supervision, statistical analysis, revising, writing and review. ABS - Conceptualization and design, statistical analysis, drafting, writing, review and editing, SS - Conceptualization and design, review, analysis investigation, SRN - Conceptualization and design, review, MA - Conceptualization and design, review, RD - Conceptualization and design, SR - review, AD - review, LG - Conceptualization and design, JMK - Conceptualization and design, GSY - Conceptualization and design, PL - Conceptualization and design, SRsr - Conceptualization and design, GG - Conceptualization and design. The author(s) read and approved the final manuscript.

\section{Funding}

The primary data collection for the Life skills training and counselling services program is funded by department of youth empowerment and sports, 
state NSS cell, government of Karnataka. However, there is no funding for the preparation of this article. In addition, the funding agency has no role in design of the study, collection, analysis and interpretation of data and in writing this article.

\section{Availability of data and materials}

The datasets used and/or analyzed during the current study are available from the corresponding author on reasonable request.

\section{Declarations}

\section{Ethics approval and consent to participate}

All necessary ethical guidelines and principles were followed in the conduct of this study. Ethical approval for this study was obtained from institutional ethics committee of NIMHANS vide letter No. NIMHANS/2 ${ }^{\text {ND }}$ IEC (BS \& NS DIV.)/2016 dated 07/12/2016. The primary data collection among participants of LSTCS program was done with written informed consent of the participants.

\section{Consent for publication}

Consent for publication is obtained as part of the written informed consent from the participants.

\section{Competing interests}

The authors declare that they have no competing interests.

\section{Author details}

${ }^{1}$ Department of Epidemiology, Centre for Public Health, NIMHANS, Bengaluru, India. ${ }^{2}$ Life Skills and Counselling Services Program, Department of Epidemiology, Centre for Public Health, NIMHANS, Bengaluru, India. ${ }^{3}$ Department of Psychiatric Social Work, NIMHANS, Bengaluru, India. ${ }^{4}$ Ramaiah International Centre for Public Health Innovations, Bengaluru, India. ${ }^{5} \mathrm{CMR}$ University Bengaluru, Bengaluru, India. ${ }^{6}$ Department of Youth Empowerment and Sports, Government of Karnataka, Bengaluru, India. ${ }^{7}$ Department of Epidemiology, Centre for Public Health, NIMHANS, Bengaluru, India.

Received: 24 April 2021 Accepted: 11 January 2022

Published online: 26 January 2022

\section{References}

1. Global Digital Overview January 2021 DataReportal [available from: [https://datareportal.com/global-digital-overview\#: :text=There\% 20are\%205.29\%20billion\%20unique,of\%201.9\%20\%\%20per\%20year.] Access on: 23 November 2021

2. Department of telecommunication report March 2019 [available from: https://dot.gov.in/sites/default/files/Annual\%20Report\%20202021\% 20English\%20Version.pdf?download=1] Access on: 29 Jan 2021

3. Shoukat S. Cell phone addiction and psychological and physiological health in adolescents. EXCLI journal. 2019;18:47.

4. Mohammadbeigi A, Absari R, Valizadeh F, Saadati M, Sharifimoghadam S, Ahmadi A, Mokhtari M, Ansari H. Sleep quality in medical students; the impact of over-use of mobile cellphone and social networks. J Res Heal Sci. 2016;16(1):46.

5. Domoff SE, Sutherland EQ, Yokum S, Gearhardt AN. Adolescents' addictive phone use: Associations with eating behaviors and adiposity. Int J Evniron Res. 2020;17(8):2861.

6. Fennell C, Barkley JE, Lepp A. The relationship between cell phone use, physical activity, and sedentary behavior in adults aged 18-80. Com H Beh. 2019;90

7. NIMHANS Centre for Well Being. Cell phone over use and addiction [available from: https://nimhans.ac.in/wp-content/uploads/2019/02/Cellphone-overuse-and-addiction.pdf. Accessed on 21 Feb 2019.

8. Kim HJ, Min JY, Kim HJ, Min KB. Accident risk associated with smartphone addiction: A study on university students in Korea. J Beh Add. 2017;6(4):699-707.

9. Overton TL, Rives TE, Hecht C, Shafi S, Gandhi RR. Distracted driving: prevalence, problems, and prevention. Int J Inj Saf. 2015;22(3):187-
10. Davey S, Davey A. Assessment of smartphone addiction in Indian adolescents: a mixed method study by systematic-review and meta-analysis approach. Int J Prev Med. 2014;5(12):1500.

11. Munderia R, Singh R. Mobile Phone Dependence and Psychological WellBeing among Young Adults. Ind J Com Psy. 2018 Sep 1;14(2):321.

12. Babadi-Akashe Z, Zamani BE, Abedini Y, Akbari H, Hedayati N. The relationship between mental health and addiction to mobile phones among university students of Shahrekord Iran. Add Hea. 2014;6(3-4):93.

13. Peraman R, Parasuraman S. Mobile phone mania: Arising global threat in public health. J Nat Sci Bio Med. 2016;7(2):198.

14. Deyan G. 51+ Scary Smartphone Addiction Statistics for 2020 [Nomophobia on the Rise]. Techjury. 22020.

15. Cheng YC, Yang TA, Lee JC. The Relationship between Smartphone Addiction, Parent-Child Relationship, Loneliness and Self-Efficacy among Senior High School Students in Taiwan. Sustainability. 2021;13(16):9475.

16. Nath A, Mukherjee S. Impact of Mobile Phone/Smartphone: A pilot study on positive and negative effects. Int J. 2015;3(5):294-302.

17. Sevim-Cirak N, Islim OF. Investigation into Nomophobia amongst Turkish pre-service teachers. Edu Inf Tech. 2021;26(2):1877-95.

18. Shahrestanaki E, Maajani K, Safarpour M, Ghahremanlou HH, Tiyuri A, Sahebkar M. The relationship between smartphone addiction and quality of life among students at Tehran University of medical sciences. Addicta: Tur J Add. 2020;7(1):61-6.

19. Uddin I, Baig A, Minhas AA. A controlled environment model for dealing with smart phone addiction. Int J Adv Com Sci App. 2018;9(9):10-4569.

20. Subramani Parasuraman AT, Yee SW, Chuon BL, Ren LY. Smartphone usage and increased risk of mobile phone addiction: A concurrent study. Int J Pha Inv. 2017;7(3):125.

21. Morris AM. Unwrapping Presence: The Impact of Cell-Phones on Face-toFace Conversations. Georgetown University; 2018.

22. Kumcagiz H, Gündüz Y. Relationship between Psychological WellBeing and Smartphone Addiction of University Students. Int J Edu. 2016:5(4):144-56.

23. StataCorp. Stata Statistical Software: Release 12. College Station: StataCorp LP; 2011.

24. De-Sola Gutiérrez J, Rodríguez de Fonseca F, Rubio G. Cell-phone addiction: A review. Fro Psy. 2016;7:175.

25. Bianchi A, Phillips JG. Psychological predictors of problem mobile phone use. Cyb Beh. 2005;8(1):39-51.

26. Mazaheri MA, Najarkolaei FR. Cell phone and internet addiction among students in Isfahan university of medical sciences-Iran. J Hea Pol Sus Hea. 2014;1(3).

27. Renuka K. Prevalence of smartphone addiction in an urban area of Kanchipuram district, Tamil Nadu: a cross sectional study. Int J Com Med. 2019;6(10):4218.

28. Lee EJ, Kim HS. Gender differences in smartphone addiction behaviors associated with parent-child bonding, parent-child communication, and parental mediation among Korean elementary school students. J Add Nur. 2018;29(4):244-54.

29. Yang SY, Lin CY, Huang YC, Chang JH. Gender differences in the association of smartphone use with the vitality and mental health of adolescent students. J Amehea. 2018;3(7):693-701.

30. Kwon M, Lee JY, Won WY, Park JW, Min JA, Hahn C, Gu X, Choi JH, Kim DJ. Development and validation of a smartphone addiction scale (SAS). PloS one. 2013;27(2):e56936.

31. Chen B, Liu F, Ding S, Ying X, Wang L, Wen Y. Gender differences in factors associated with smartphone addiction: a cross-sectional study among medical college students. BMC Psy. 2017;17(1):1-9.

32. Choi SW, Kim DJ, Choi JS, Ahn H, Choi EJ, Song WY, Kim S, Youn H. Comparison of risk and protective factors associated with smartphone addiction and Internet addiction. J Beh Add. 2015;4(4):308-14.

33. Bae SM. The relationships between perceived parenting style, learning motivation, friendship satisfaction, and the addictive use of smartphones with elementary school students of South Korea: Using multivariate latent growth modeling. Sch Psy Int. 2015;36(5):513-31.

34. Alavi SS, Ghanizadeh M, Mohammadi MR, Kalhory SM, Jannatifard F, Sepahbodi G. The survey of personal and national identity on cell phone addicts and non-addicts. Iran J Psy. 2018;13(1):15.

35. Celikkalp U, Bilgic S, Temel M, Varol G. The smartphone addiction levels and the association with communication skills in nursing and medical school students. J Nur Res. 2020;28(3):e93. 
36. Siu MY. Association between use of internet and quality of life (qol) among young people in Hong Kong. Nurs Pract Health Care. 2019;1(1):103.

37. Kumcagiz H. Quality of life as a predictor of smartphone addiction risk among adolescents. Tec, KnoLea. 2019;24(1):117-27.

38. Winkler A, Jeromin F, Doering BK, Barke A. Problematic smartphone use has detrimental effects on mental health and somatic symptoms in a heterogeneous sample of German adults. Com Hum Beh. 2020;113:106500

39. Lemmens JS, Valkenburg PM, Peter J. Development and validation of a game addiction scale for adolescents. Med Psy. 2009;26(1):77-95.

40. Petry NM, Rehbein F, Gentile DA, Lemmens JS, Rumpf HJ, Mossle T, Bischof G, Tao R, Fung DS, Borges $G$ et al. An international consensus for assessing internet gaming disorder using the new DSM-5 approach. Add. 2014

41. Horvath CW. Measuring television addiction. J Bro Ele Med. 2004;48(3):378-98

42. Lam LT, Peng ZW, Mai JC, Jing J. Factors associated with Internet addiction among adolescents. Cyb Beh. 2009:12(5):551-5.

43. Young KS. Internet addiction test. Cen on-line add. 2009.

44. Whogol Group. Development of the World Health Organization WHOQOL-BREF quality of life assessment. Psy Med. 1998;28(3):551-8.

45. Vranda MN. Development and standardization of life skills scale. Ind J Soc Psy. 2009;25(1/2):17-28.

46. Rammstedt B, John OP. Measuring personality in one minute or less: A 10-item short version of the Big Five Inventory in English and German. J Res Per. 2007:41:203-12.

\section{Publisher's Note}

Springer Nature remains neutral with regard to jurisdictional claims in published maps and institutional affiliations.

- fast, convenient online submission

- thorough peer review by experienced researchers in your field

- rapid publication on acceptance

- support for research data, including large and complex data types

- gold Open Access which fosters wider collaboration and increased citations

- maximum visibility for your research: over $100 \mathrm{M}$ website views per year

At BMC, research is always in progress.

Learn more biomedcentral.com/submissions 